\title{
Evaluation of Growth Traits and Tibiae Health in Sexed Indigenous Turkeys with Different Feather Colours Under Deep Litter and Outdoor Run Houses
}

\author{
Kamorudeen SAFIYU ${ }^{1 *}$, Olajide SOGUNLE ${ }^{1}$, Lawrence EGBEYALE ${ }^{1}$, Taofik SHITTU ${ }^{2}$, Olusola ODUTAYO ${ }^{1}$, \\ Jubril MUSTAPHA ${ }^{1}$, Arumbackam V. ELANGOVAN ${ }^{3}$ \\ ${ }^{1}$ Department of Animal Production and Health, Federal University of Agriculture, Abeokuta, Ogun State, Nigeria \\ ${ }^{2}$ Department of Food Science and Technology, Federal University of Agriculture, Abeokuta, Ogun State, Nigeria \\ ${ }^{3}$ India Council for Agricultural Research - National Institute of Animal Nutrition and Physiology (ICAR- \\ NIANP), Bengaluru, India. \\ *corresponding author: safiyu.kamorudeenk@pg.funaab.edu.ng
}

Bulletin UASVM Veterinary Medicine 76(1)/2019

Print ISSN 1843-5270; Electronic ISSN 1843-5378

doi:10.15835/buasvmcn-vm: 2018.0049

\section{Abstract}

The study consisted of 400 sexed turkeys, grouped on the basis of 2 distinct feather colours (white and black) into deep litter and outdoor, respectively. Day-old poults were brooded for 4 weeks and acclimatized in both houses for 2 weeks before the commencement of the study that lasted for 10 weeks. At the end of the trial, 2 birds per replicate were sacrificed and left tibiae were removed for morphometric and mineral analyses. Data were arranged in a $2 \times 2 \times 2$ factorial layout and subjected to Analysis of Variance in a Completely Randomized Design. Results showed water intake and water: feed were significantly $(\mathrm{p}<0.05)$ higher in turkeys reared on deep litter. Also, male turkeys recorded significantly $(\mathrm{p}<0.05)$ higher weight gain, feed and water intakes, and better feed conversion ratio than female turkeys. Tibia length and ash weight were significantly $(\mathrm{p}<0.05)$ greater in turkeys reared in deep litter than turkeys in outdoor. Tibiae phosphorus was significantly influenced by interactions of sex by feather colour as well as housing system by sex by feather colour. Therefore, female turkeys with either white or black feathers could be reared in outdoor-run for strong tibiae with predominant bone mineral (Ca and P) matrix.

Keywords: indigenous turkeys, housing system, sex, feather colour, tibiae health

\section{Introduction}

Turkeys (Meleagris gallopavo) are adaptable to a wide range of climatic conditions and can be raised successfully almost anywhere in the world (Speller, 2009; Odutayo et al., 2015). However, turkey production in tropical and sub-tropical countries involves mostly the rearing of indigenous turkey species at the smallholder level (Ojewola et al., 2002; Okoli et al., 2009). To the poor majority in rural areas, local poultry serve as an immediate source of meat and income for urgent family needs
(Ekue et al., 2002; Padhi, 2016). These birds are generally hardy, disease resistant and can thrive and produce with irregular supply of feed and water and with minimum healthcare (Ajayi, 2010; Padhi, 2016). Indigenous turkeys are available with a wide variety of colourful feathers with yet no discrimination against any particular feather colour. Colour traits of feathers act as condition-dependent indicators of male viability and mate choice in female birds (MacDougall and Montgomerie, 2003; Hill et al., 2005). However, information 
about the relationship between feather colour and performance of indigenous turkeys is still insufficient to assess its use in commercial production.

The extensive genetic diversity embedded in indigenous poultry species allows rearing under varied environmental conditions for the provision of a range of products and functions (Sonaiya et al., 1999). Indigenous poultry are mostly reared in rural backyard poultry production systems where they exhibit their natural behaviour (such as foraging, dust bathing and scratching) due to ample space and access to diverse resources (Bracke and Hopster, 2006); thereby yielding products with better taste and flavour compared to intensively reared birds (Fanatico et al., 2006; Sogunle et al., 2014). However, their productive potential in growth has not been fully exploited. Researchers (Sarkar and Golam, 2009; Okeno et al., 2012) have established that changes in production system can improve poultry performance, hence best rearing system that conform to the code of practice for the care and handling of poultry species should be adopted (Case et al., 2010; NFACC, 2016).

Though the growth rate of turkeys has increased over the years (Havenstein et al., 2007), the occurrence of leg fractures is a major problem affecting turkey flock. Leg problems associated with bone weakness are prevalent in large-size poultry which render them lame leading to the deterioration of their gait scores, performance and welfare (Zhou et al., 2011). Under normal conditions, bones respond to increased body weight by continually increasing their rates of remodelling (Turner and Robling, 2004), but bones of heavier birds are often abnormally developed with high porosity and much lower density which may eventually lead to bone fracture (Williams et al., 2004; Bennett, 2008). These fractures are a major concern to turkey producers, as the fractured bone may lacerate the artery and result in death (Van Wyhe et al., 2014). Researchers (Rath et al., 2000; Dawkins et al.,
2004; Knowles et al., 2008) have attributed stressors of non-infectious origins in different poultry houses such as overcrowding and the lack of exercise as few of the various physical and environmental constraints that can deteriorate skeletal health. Hence, improved housing systems that is welfare-friendly and accommodates the large body mass of turkeys with respect to its concomitant increase in the size and strength of skeletal structure needs to be investigated (Warden, 2006).

This study therefore aimed to compare the growth performance, tibiae morphometry and minerals ( $\mathrm{Ca}$ and $\mathrm{P}$ ) of sexed indigenous turkeys with different feather colours under deep litter and outdoor houses.

\section{Materials and Methods Experimental Site}

This experiment was carried out at the Poultry Unit of the Directorate of University Farms (DUFARMS), Federal University of Agriculture, Abeokuta, Ogun state, Nigeria which was situated at an altitude of 148 meters between latitude $7^{\circ}$ $13^{\prime} \mathrm{N}$ and longitude $3^{\circ} 26^{\prime} \mathrm{E}$ (Federal University of Agriculture, Abeokuta Agro-meteorology Unit).

\section{Experimental birds management}

The study consisted of sexed turkeys (male and female), grouped on basis of 2 distinct feather colours (white and black) into deep litter and outdoor houses, respectively for a total of 400 birds in an experiment that lasted for 10 weeks. Two hundred (200) sexed day-old poults with white feathers and 200 sexed day-old poults with black feathers were brooded separately in an environmentally controlled house for 4 weeks. After brooding, birds were acclimatized in deep litter and outdoor run houses for 2 weeks before the commencement of the study.

Research Bioethics Animal Ethics Committee guidelines of the Federal University of Agriculture, Abeokuta (FUNAAB, 2014) were strictly adhered to throughout the duration of the experiment.

Description of Experimental Houses Individual indoor pen (deep litter) and outdoor mini-shelter used for turkey rearing on outdoor run in this study were constructed with a stocking density of $0.4 \mathrm{~m}^{2}$ per turkey. However, turkeys in outdoor system had access to runs with a stocking 
density of $4 \mathrm{~m}^{2}$ per turkey for birds to exhibit their natural behaviour (such as foraging, dust bathing and scratching) and access to diverse resources similar to its natural habitat.

\section{Experimental Diet}

The diet formulated during the experiment met the recommendations of National Research Council (NRC, 1994). Pre-starter from 1-3 weeks of age, starter from 3-6 weeks of age, grower from 6-9 weeks of age and finisher from 9-16 weeks of age. The birds under deep litter had access to ad libitum supply of formulated feed and water throughout the experimental period. However, birds under outdoor system had access to Scavengeable Feed Resource Base (SFRB) which included; household cooking waste, cereal and cereal by-products, vegetable weed particularly Talinum triangulare, shrubs, sedges and grasses (including, Heliotropium indicum Linn, Cyperus iria Linn, Eragrostistenella and Eleusine indica Graertn), animal proteins (maggots and earthworms) and the formulated ration. As enunciated by Olaniyi et al. (2012), the value of the SFRB was estimated by weighing the amount of daily feed product/ household waste generated by families around the experimental site as parameter ' $\mathrm{H}$ ' divided by the proportion of feed product/household waste found in the crop of the scavenging turkeys (assessed visually) as parameter ' $p$ ' and multiplied by the percentage of household that kept chickens ' $c$ '. The formula used was:

$$
\mathrm{SFRB}=\frac{\mathrm{H}}{\mathrm{p}} \times \mathrm{c} \frac{\mathrm{H}}{\mathrm{p}} \times \mathrm{c}
$$

\section{Experimental Design}

The experiment was arranged in a $2 \times 2 \times 2$ factorial layout. There were 8 treatments consisting of 50 birds per treatment. Each treatment was further sub-divided into five replicates of 10 birds each using numbered rings for identification. The descriptions of experimental treatments are as follows;

Treatment 1: male turkeys with white feathers under deep litter

Treatment 2: female turkeys with white feathers under deep litter

Treatment 3: male turkeys with black feathers under deep litter

Treatment 4: female turkeys with black feathers under deep litter
Treatment 5: male turkeys with white feathers under outdoor

Treatment 6: female turkeys with white feathers under outdoor

Treatment 7: male turkeys with black feathers under outdoor

Treatment 8: female turkeys with black feathers under outdoor

Data collection

\section{Growth Performance}

Body weight, feed and water intakes were recorded. The feed conversion ratio (FCR) was calculated using the formula: FCR $=$ (Feed intake) weight gain). Feed to Water ratio of birds in each replicate was calculated as the ratio of feed intake to water intake using the formula: water to feed ratio $=($ Feed intake $/$ water intake $)$.

\section{Tibiae morphometry}

At the end of the trial, two birds from each replicate were sacrificed through cervical dislocation and their left tibiae were removed for morphometric and mineral composition analyses as described by Sogunle et al. (2018). Tibiae measurements were carried out in the Laboratory of the Department of Animal Production and Health, Federal University of Agriculture, Abeokuta.

The tibiae weights were measured using scientific sensitive scale. Tibia length, proximal width, mid-shaft width and distal width were measured with vernier callipers. The tibiae weight/length index was obtained by dividing the tibia weight by its length (Seedor et al., 1991), while robusticity index was determined using the following formula as described by Mutus et al. (2006): Robusticity index $=$ (Bone length $/$ Cube root of tibia weight)

\section{Determination of tibiae minerals (Calcium and Phosphorus)}

Each tibia was defatted for 16 hours in petroleum ether (boiling point of 60-80 ${ }^{\circ} \mathrm{C}$ ), dried and weighed before ashing in a muffle furnace. The samples were digested with diluted hydrochloric acid (1:2) and mineral extract was prepared according to AOAC (1995). The extract from each replicate was selected and the concentration of calcium (Ca) and phosphorus (P) were determined by Inductively Coupled Plasma Optical Emission Spectrometry.

\section{Statistical Analysis}

Data obtained were arranged in $2 \times 2 \times 2$ factorial layout and subjected to Analysis of 
Table 1. Effects of housing system, feather colour and sex on growth performance of turkeys

\begin{tabular}{llccccc}
\hline \multirow{2}{*}{ Parameters } & & $\begin{array}{c}\text { AVG (g/ } \\
\text { bird/day) }\end{array}$ & $\begin{array}{c}\text { AFI (g/ } \\
\text { bird/day) }\end{array}$ & FCR & $\begin{array}{c}\text { AWI (ml/ } \\
\text { bird/day) }\end{array}$ & $\begin{array}{c}\text { WFR } \\
\text { (ml/g) }\end{array}$ \\
\hline \multirow{2}{*}{ Housing system } & Deep litter & 30.03 & 131.21 & 4.45 & $338.04^{\mathrm{a}}$ & $2.58^{\mathrm{a}}$ \\
\cline { 2 - 7 } Feather colour & Outdoor run & 30.73 & 130.05 & 4.34 & $301.24^{\mathrm{b}}$ & $2.32^{\mathrm{b}}$ \\
\hline \multirow{2}{*}{ Sex } & White & 30.31 & 130.09 & 4.37 & 318.22 & 2.45 \\
\cline { 2 - 7 } & Black & 30.46 & 131.18 & 4.42 & 321.06 & 2.45 \\
\hline SEM & Tom & $36.16^{\mathrm{a}}$ & $141.98^{\mathrm{a}}$ & $3.94^{\mathrm{b}}$ & $333.05^{\mathrm{a}}$ & $2.34^{\mathrm{b}}$ \\
\hline Hen & $24.60^{\mathrm{b}}$ & $119.29^{\mathrm{b}}$ & $4.86^{\mathrm{a}}$ & $306.23^{\mathrm{b}}$ & $2.57^{\mathrm{a}}$ \\
\hline $\mathrm{P}$ value & 0.56 & 3.37 & 0.12 & 7.70 & 0.01 \\
\hline $\mathrm{HS}$ & & & & & 0.004 & 0.002 \\
\hline $\mathrm{FC}$ & 0.389 & 0.810 & 0.523 & 0.797 & 0.997 \\
\hline $\mathrm{S}$ & 0.847 & 0.823 & 0.778 & 0.026 & 0.010 \\
\hline $\mathrm{HS} \times \mathrm{FC}$ & $<0.001$ & $<0.001$ & $<0.001$ & 0.627 & 0.762 \\
\hline $\mathrm{HS} \times \mathrm{S}$ & 0.752 & 0.585 & 0.458 & 0.036 & 0.023 \\
\hline $\mathrm{S} \times \mathrm{FC}$ & 0.018 & 0.031 & 0.013 & 0.660 & 0.689 \\
\hline $\mathrm{HS} \times \mathrm{S} \times \mathrm{FC}$ & 0.369 & 0.919 & 0.466 & 0.032 & 0.036 \\
\hline
\end{tabular}

Means on the same column having different superscript differ significantly at $P<0.05$.

AVG: Average Weight gain, AFI: Average feed intake, FCR: Feed Conversion Ratio, AWI: Average water intake, WFR: water-feed intake ratio, HS: Housing system, FC: Feather colour, S: Sex.

Variance in a Completely Randomized Design. Significant differences between means were separated using Tukey Test as contained in Minitab $^{\circledR}$ version 17.1.0 (Minitab, 2013) at 5\% probability level. Also, prediction equations were used to determine the best model fit.

\section{Results and discussions Growth performance}

The effects of housing system, feather colour and sex on growth performance of indigenous turkeys are depicted in Table 1. Average water intake was significantly $(\mathrm{p}<0.05)$ higher $(338.04$ $\mathrm{g} /$ bird/day) in turkeys reared on deep litter and lower (301.24 g/bird/day) in turkeys reared outdoor. This result could be due to the fact that turkeys under outdoor run system spent more time scavenging in the outside run and had access to available droplets of water on plant surfaces unlike turkeys in deep litter that had no alternative source of water except the water provided. This corroborated earlier reports by
Duncan (1998) who stated that domestic poultry are likely to exhibit a "natural" drinking behaviour when raised in range system where birds drink by pecking at dew drops on plants. Water-feed intake ratio was also significantly $(\mathrm{p}<0.05)$ higher $(2.58$ $\mathrm{ml} / \mathrm{g}$ ) in turkeys reared on deep litter and lower $(2.32 \mathrm{ml} / \mathrm{g})$ in turkeys under outdoor houses.

The ratio of water intake to feed intake appear to be potentially important in the therapy of sick birds but, hitherto, no specific comparison of the water-feed intake ratio of sick and healthy turkeys seems to have been carried out. Thus, values for water-feed intake ratio recorded in this study fell within the range reported by Williams (1996) for water to feed ratio in poultry. However, feather colour had no significant ( $p>0.05$ ) influence on growth performance of turkeys.

This negated previous studies where a depressive effect of the recessive white-plumage colour on growth rate was reported in quail (Minvielle et al., 2002; Petek et al., 2004) and chickens (Fox and Smyth, 1982). Inci et al. (2015) 


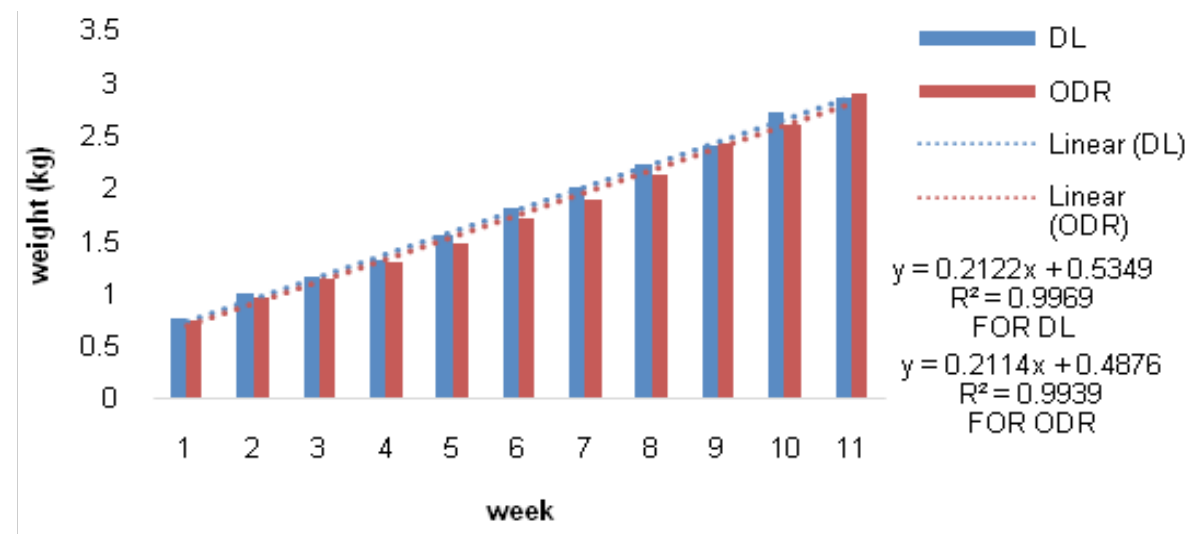

Figure 1. Linear Growth curve fit for Housing System. DL: Deep Litter; ODR: Outdoor run

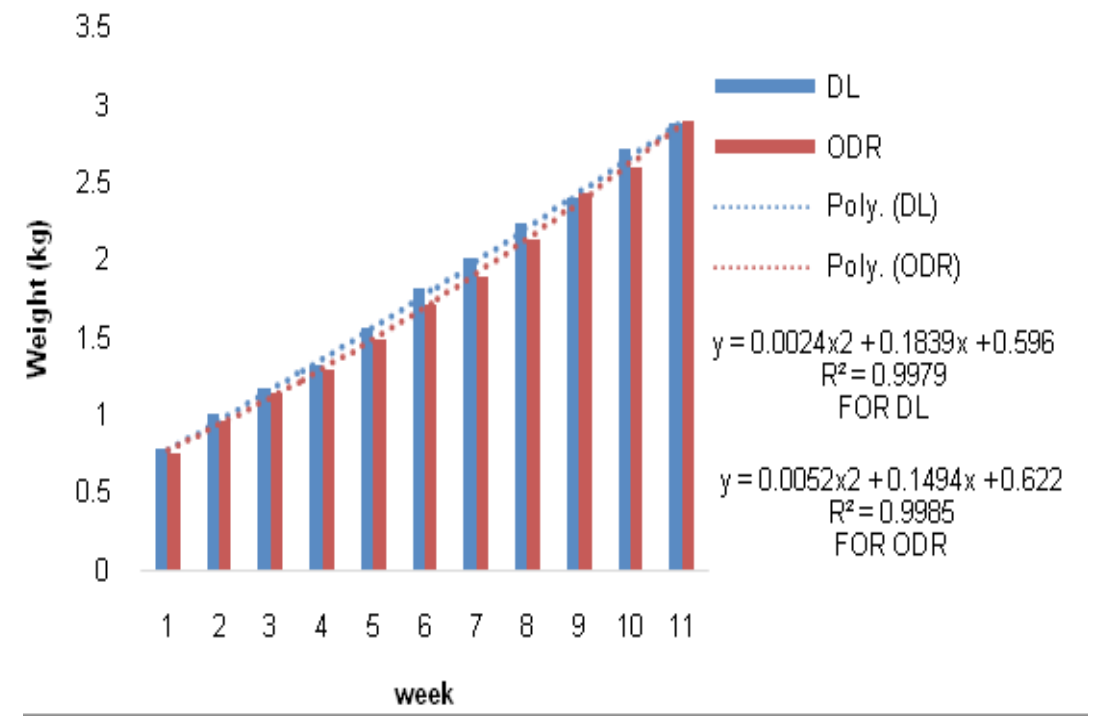

Figure 2. Quadratic Growth curve fit for Housing System. DL = Deep Litter, ODR: Outdoor run

also observed significant differences in feed intake and FCR of Japanese quails with different feather colours. This variation in results could be attributed to differences in species of poultry reared.

Also, the effect of sex significantly $(\mathrm{p}<0.05)$ influenced all parameters measured. Male turkeys recorded significantly $(\mathrm{p}<0.05)$ higher values for average weight gain (36.16 g/bird/day), average feed and water intakes (141.98 g/bird/day and $333.05 \mathrm{ml} / \mathrm{bird} /$ day, respectively) relative to values (24.60 g/bird/day, $119.29 \mathrm{~g} /$ bird/day and 306.23 $\mathrm{ml} /$ bird/day) recorded in female turkeys. Higher body weights recorded in male turkeys could be as a result of higher feed intake and its better physiological capacity in converting feed into body weight. On the other hand, FCR and water-feed intake ratio were significantly $(p<0.05)$ better (3.94 and $2.34 \mathrm{ml} / \mathrm{g}$ ) in male turkeys than (4.86 and $2.57 \mathrm{ml} / \mathrm{g}$ ) recorded in female turkeys. These findings further augmented earlier studies on broilers (Noraziah et al., 2001; Liu et al., 2006) as well as turkeys (Sola-Ojo et al., 2016). There were significant interaction effects of housing system by sex and housing system by sex by feather colour on all the parameters considered. This thereby shows the relative influence of housing system on growth performance of the turkey.

In Figure 1, the linear growth curve of indigenous turkeys on deep litter had a coefficient of regression $\left(\mathrm{R}^{2}\right)$ of 0.9969 with a prediction equation of $\mathrm{y}=0.2122 \mathrm{x}+0.5349$. Turkeys on 


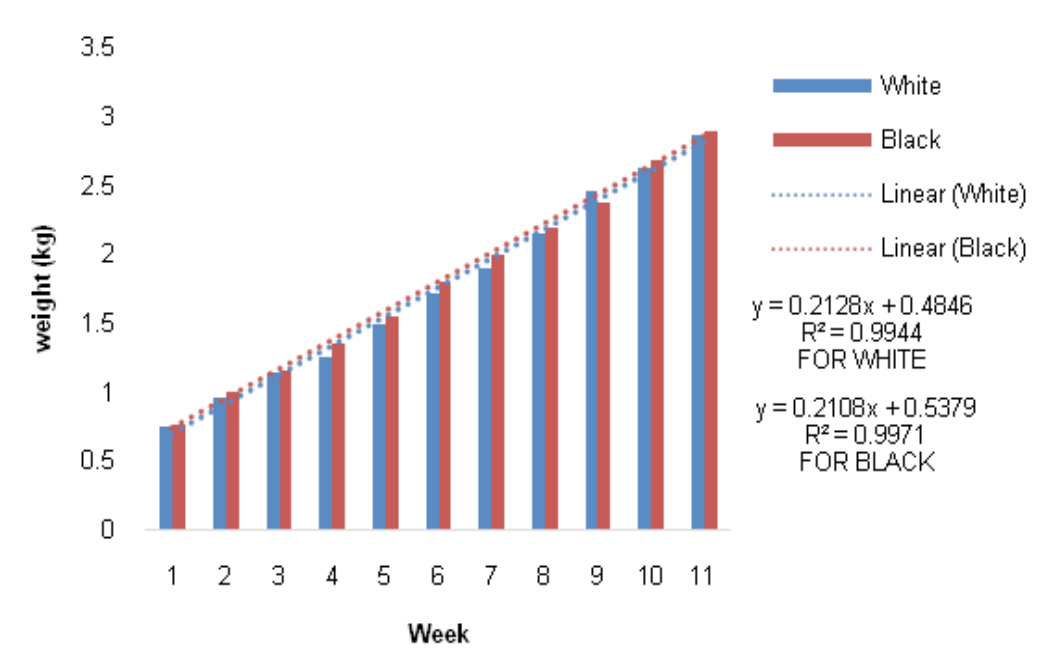

Figure 3. Linear Growth curve fit for Feather colour

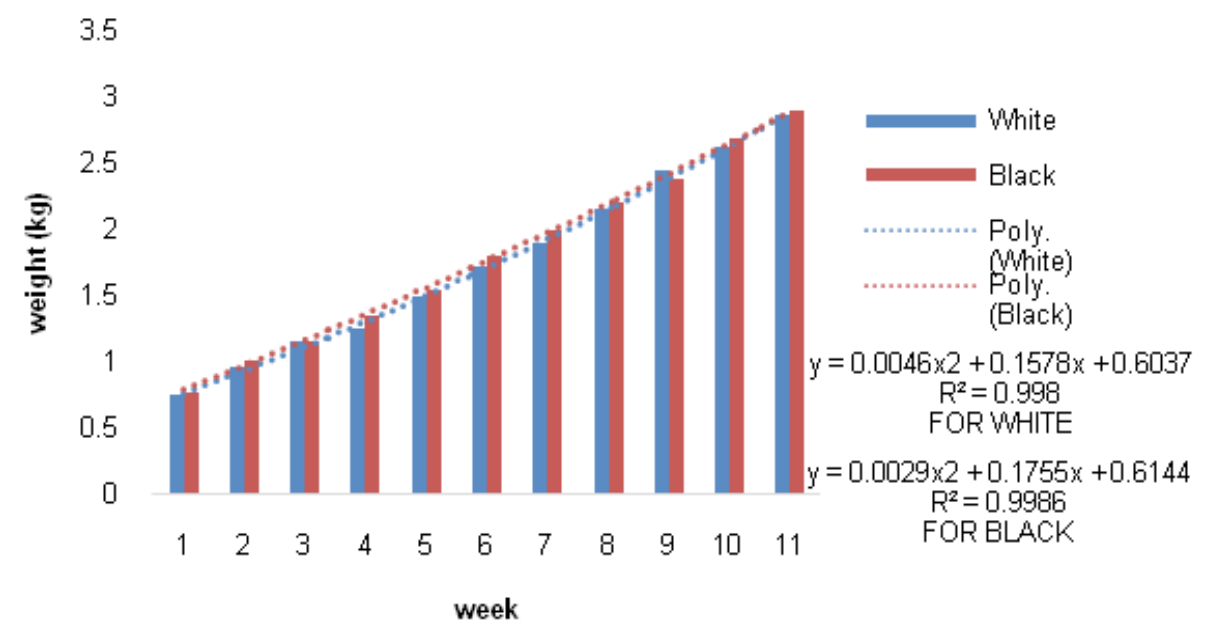

Figure 4. Quadratic Growth curve fit for Feather colour

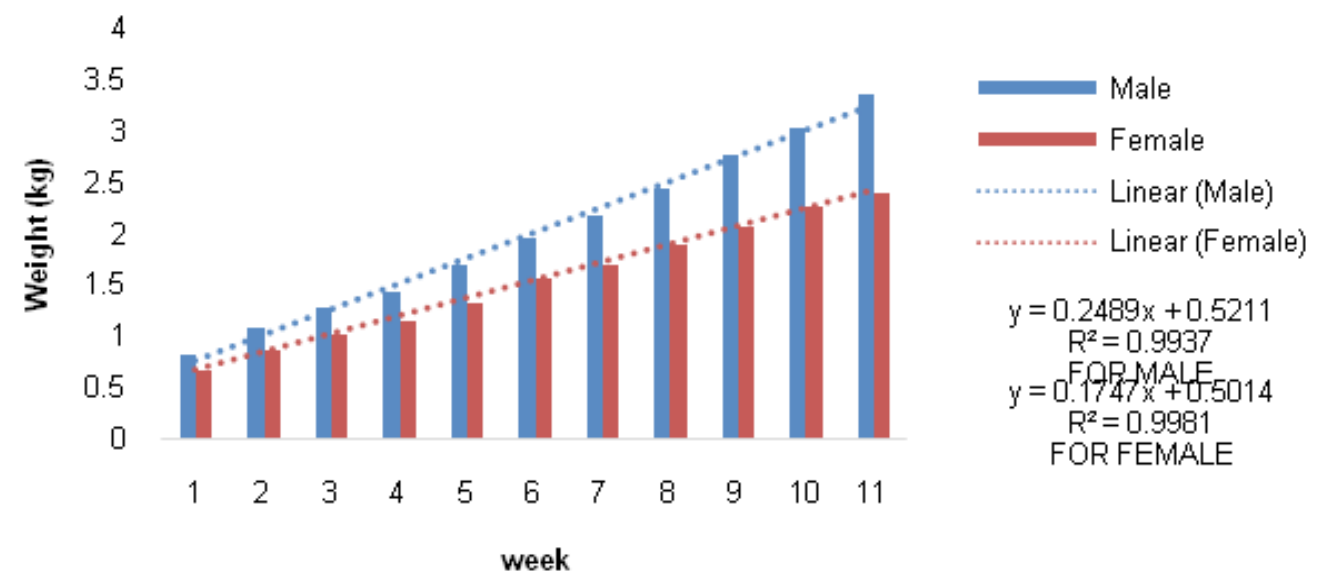

Figure 5. Linear growth curve fit for sex 


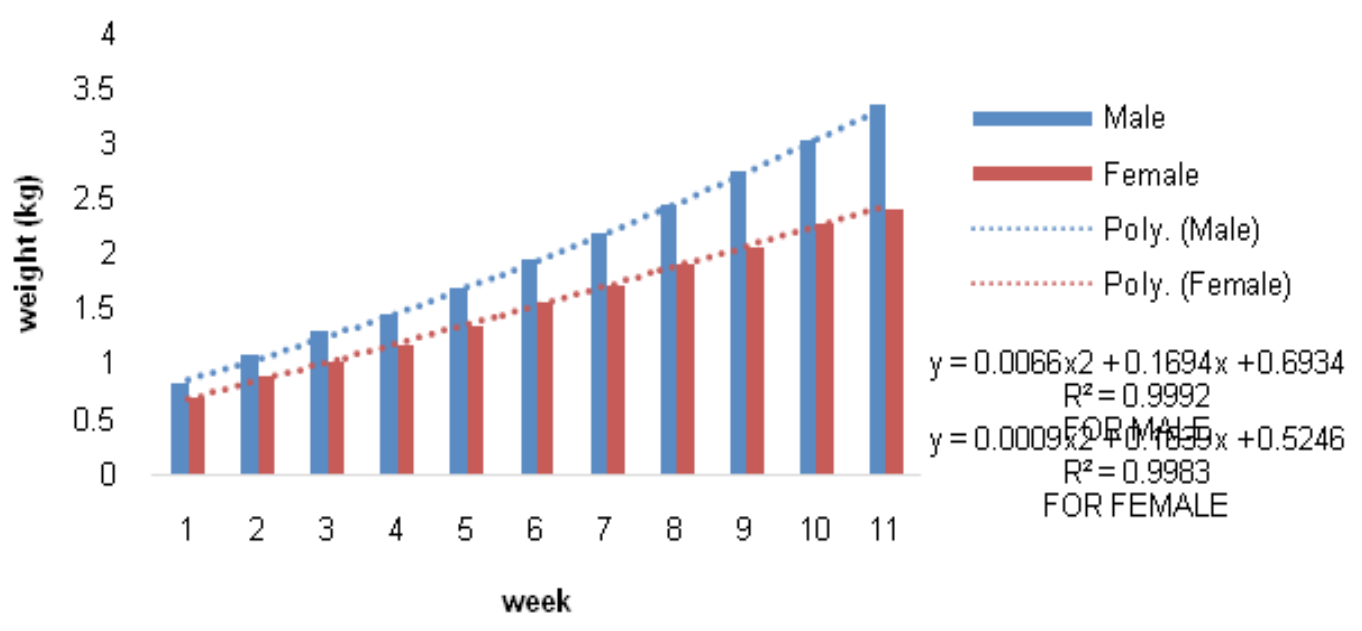

Figure 6. Quadratic growth curve fit for sex

outdoor run recorded a $\mathrm{R}^{2}$ value of 0.9939 with a prediction equation of $\mathrm{y}=0.2114 \mathrm{x}+0.4876$. However, in the quadratic growth curve (Figure 2 ), the prediction for turkeys on deep litter is $y$ $=0.0024 \mathrm{x}^{2}+0.1839 \mathrm{x}+0.596\left(\mathrm{R}^{2}: 0.9979\right)$ while $\mathrm{y}=0.0052 \mathrm{x}^{2}+0.1494 \mathrm{x}+0.622\left(\mathrm{R}^{2}: 0.9985\right)$ was predicted for turkeys on outdoor run. In figure 3 , the linear curve for turkeys with white feathers had an equation of $\mathrm{y}=0.2128 \mathrm{x}+0.4846\left(\mathrm{R}^{2}\right.$ : $0.9944)$ while $y=0.2108 x+0.5379\left(R^{2}: 0.9971\right)$ was predicted for turkeys with black feathers.

But in Figure 4, the quadratic growth curve for turkeys with different feather colour revealed equations; $y=0.0046 x^{2}+0.1578 x+0.6037\left(R^{2}\right.$ : 0.998 ) for turkeys with white feathers and $y=$ $0.0029 x^{2}+0.1755 x+0.6144\left(R^{2}: 0.9986\right)$ for turkeys with black plumages.

Linear curve fit of growth for sex shown in Figure 5 revealed a prediction equation of $\mathrm{y}=$ $0.2489 x+0.5211\left(R^{2}: 0.9937\right)$ for male turkeys while female turkeys had an equation; $\mathrm{y}=0.1747 \mathrm{x}$ $+0.5014\left(\mathrm{R}^{2}: 0.9981\right)$.

In Figure 6, the quadratic curve fit of growth for sex is shown. Male turkeys had a prediction equation of $y=0.0066 x^{2}+0.1694 x+0.6934\left(R^{2}\right.$ : 0.9992 ) while female turkeys had a prediction equation of $y=0.0009 x^{2}+0.1639 x+0.5246\left(R^{2}\right.$ : 0.9983).

The linear, exponential and quadratic curves used to explain the variation in body weight as affected by housing system, feather colour and sex best fit the quadratic curve as a result of higher values recorded for $\mathrm{R}^{2}$.
This corroborated the reports of Goliomytis et al. (2003) where the high values for coefficient of determination indicates the excellent fit of the Richards function to body weight.

\section{Tibiae morphometry}

The effects of housing system, feather colour and sex on tibia morphometry of turkeys are shown in Table 2. Tibia length and ash weight were significantly $(\mathrm{p}<0.05)$ greater $(103.96 \mathrm{~mm}$ and $4.03 \mathrm{~g}$ ) in turkeys reared in deep litter than observed values ( $101.40 \mathrm{~mm}$ and $3.48 \mathrm{~g}$ ) in turkeys under outdoor run. Also, significantly $(\mathrm{p}<0.05)$ higher tibia length (101.43 $\mathrm{mm})$ was recorded in black-feathered turkeys and lower (103.93) in turkeys with white feather. Avian bone is a dynamic tissue influenced by physiological, nutritional, and physical factors such as mechanical stress and physical activities (Rath et al., 2000). Hence, a good grasp of the concept of mineralization of bone matrix with respect to its physical and chemical structure is of great economic importance for growth and metabolism of meat-type poultry species, however literature is limited on the comparison of bone quality measurements from turkeys reared in different housing systems.

In view of this, our findings contrasted earlier reports on broiler chicken (Tolon and Yalcin, 1997; Olaifa et al., 2015; Özhan et al., 2016) where negligible means were reported for bone measurements obtained from birds reared in different housing systems. Housing by sex by feather colour interaction significantly affected all tibiae morphometric indices except relative 
Table 2. Effects of housing system, feather colour and sex on tibiae morphometry of turkeys

\begin{tabular}{|c|c|c|c|c|c|c|c|c|c|c|}
\hline \multicolumn{2}{|c|}{ Parameters } & $\begin{array}{c}\text { Weight } \\
\text { (g) }\end{array}$ & $\begin{array}{l}\text { Length } \\
\text { (mm) }\end{array}$ & $\begin{array}{c}\text { Mid } \\
\text { shaft } \\
\text { width } \\
(\mathrm{mm})\end{array}$ & $\begin{array}{c}\text { Proxi- } \\
\text { mal } \\
\text { width } \\
(\mathrm{mm})\end{array}$ & $\begin{array}{l}\text { Distal } \\
\text { width } \\
(\mathrm{mm})\end{array}$ & $\begin{array}{c}\text { Weight: } \\
\text { length } \\
\text { index } \\
\text { (mg/ } \\
\text { cm) }\end{array}$ & $\begin{array}{c}\text { Relative } \\
\text { bone } \\
\text { density } \\
\left(\mathrm{gcm}^{-3}\right)\end{array}$ & $\begin{array}{l}\text { Robus- } \\
\text { ticity } \\
\text { index } \\
\left(\mathrm{cmg}^{-1 / 3}\right)\end{array}$ & $\begin{array}{c}\text { Ash } \\
\text { weight } \\
\text { (g) }\end{array}$ \\
\hline \multirow{2}{*}{$\begin{array}{l}\text { Housing } \\
\text { system }\end{array}$} & $\begin{array}{l}\text { Deep } \\
\text { litter }\end{array}$ & 11.00 & $103.96^{\mathrm{a}}$ & 10.52 & 25.86 & 22.67 & 104.56 & 0.38 & 2.96 & $4.03^{\mathrm{a}}$ \\
\hline & $\begin{array}{l}\text { Outdoor } \\
\text { run }\end{array}$ & 10.02 & $101.40^{\mathrm{b}}$ & 10.48 & 25.27 & 22.47 & 97.66 & 0.37 & 3.16 & $3.48^{\mathrm{b}}$ \\
\hline \multirow{2}{*}{$\begin{array}{l}\text { Feather } \\
\text { colour }\end{array}$} & White & 10.18 & $101.43^{\mathrm{b}}$ & 10.47 & 25.42 & 22.43 & 99.28 & 0.37 & 3.11 & 3.70 \\
\hline & Black & 10.84 & $103.93^{\mathrm{a}}$ & 10.54 & 25.71 & 22.73 & 102.93 & 0.39 & 3.00 & 3.81 \\
\hline \multirow{2}{*}{ Sex } & Male & $12.76^{\mathrm{a}}$ & $109.99^{a}$ & $11.23^{\mathrm{a}}$ & $27.45^{\mathrm{a}}$ & $24.52^{\mathrm{a}}$ & $115.68^{\mathrm{a}}$ & $0.40^{\mathrm{a}}$ & $2.64^{\mathrm{b}}$ & $4.43^{\mathrm{a}}$ \\
\hline & Female & $8.26^{b}$ & $95.37^{b}$ & $9.77^{b}$ & $23.68^{b}$ & $20.62^{\mathrm{b}}$ & $86.53^{b}$ & $0.36^{\mathrm{b}}$ & $3.48^{\mathrm{a}}$ & $3.06^{b}$ \\
\hline SEM & & 0.36 & 0.79 & 0.19 & 0.24 & 0.26 & 2.98 & 0.01 & 0.09 & 0.08 \\
\hline \multicolumn{11}{|l|}{ P value } \\
\hline HS & & 0.084 & 0.043 & 0.880 & 0.114 & 0.601 & 0.133 & 0.297 & 0.161 & $<0.001$ \\
\hline $\mathrm{FC}$ & & 0.228 & 0.048 & 0.816 & 0.410 & 0.412 & 0.413 & 0.212 & 0.412 & 0.391 \\
\hline$S$ & & $<0.001$ & $<0.001$ & $<0.001$ & $<0.001$ & $<0.001$ & $<0.001$ & 0.016 & $<0.001$ & $<0.001$ \\
\hline $\mathrm{HS} \times \mathrm{FC}$ & & 0.331 & 0.045 & 0.674 & 0.481 & 0.765 & 0.323 & 0.551 & 0.295 & 0.041 \\
\hline $\mathrm{HS} \times \mathrm{S}$ & & 0.028 & 0.039 & 0.048 & 0.042 & 0.034 & 0.014 & 0.479 & 0.022 & 0.067 \\
\hline $\mathrm{S} \times \mathrm{FC}$ & & 0.024 & 0.026 & 0.010 & 0.049 & 0.013 & 0.047 & 0.801 & 0.027 & 0.039 \\
\hline $\mathrm{HS} \times \mathrm{S} \times \mathrm{FC}$ & & 0.041 & 0.030 & 0.023 & 0.012 & 0.039 & 0.032 & 0.897 & 0.037 & 0.026 \\
\hline
\end{tabular}

Means on the same column having different superscript differ significantly at $P<0.05$. HS = Housing system, $\mathrm{FC}=$ Feather colour, $\mathrm{S}=\mathrm{Sex}$

Table 3. Effects of housing system, feather colour and sex on tibiae minerals of turkeys

\begin{tabular}{|c|c|c|c|c|}
\hline \multicolumn{2}{|c|}{ Parameters } & \multirow{2}{*}{$\begin{array}{c}\text { Bone Mineral Content (\%) } \\
37.01 \\
\end{array}$} & \multirow{2}{*}{$\frac{\text { Calcium (\%) }}{4.31^{\mathrm{a}}}$} & \multirow{2}{*}{$\begin{array}{c}\text { Phosphorus (\%) } \\
7.92 \\
\end{array}$} \\
\hline Housing system & Deep litter & & & \\
\hline & Outdoor run & 35.36 & $2.25^{\mathrm{b}}$ & 9.43 \\
\hline \multirow[t]{2}{*}{ Feather colour } & White & 36.88 & 2.81 & 8.54 \\
\hline & Black & 35.49 & 3.75 & 8.85 \\
\hline \multirow[t]{2}{*}{ Sex } & Male & 35.06 & $2.24^{\mathrm{b}}$ & $6.49^{\mathrm{b}}$ \\
\hline & Female & 37.31 & $4.32^{\mathrm{a}}$ & $10.86^{\mathrm{a}}$ \\
\hline SEM & & 0.89 & 0.53 & 0.58 \\
\hline \multicolumn{5}{|l|}{ P value } \\
\hline HS & & 0.221 & 0.025 & 0.102 \\
\hline FC & & 0.300 & 0.248 & 0.686 \\
\hline$S$ & & 0.101 & 0.024 & 0.001 \\
\hline $\mathrm{HS} \times \mathrm{FC}$ & & 0.166 & 0.897 & 0.690 \\
\hline $\mathrm{HS} \times \mathrm{S}$ & & 0.634 & 0.031 & 0.033 \\
\hline $\mathrm{S} \times \mathrm{FC}$ & & 0.835 & 0.485 & 0.046 \\
\hline $\mathrm{HS} \times \mathrm{S} \times \mathrm{FC}$ & & 0.144 & 0.486 & 0.043 \\
\hline
\end{tabular}

Means on the same column having different superscript differ significantly at $P<0.05$.

$\mathrm{HS}=$ Housing system, $\mathrm{FC}=$ Feather colour, $\mathrm{S}=\mathrm{Sex}$ 
bone density. Disparity in present and past results could be attributed to differences in poultry species used. In a study by Lilburn (1994) where skeletal growth of commercial poultry species were compared, relative tibia development was significantly lower in broilers compared with turkeys and ducks. In addition, sex significantly $(p<0.05)$ influenced all tibiae morphometric parameters with higher values for tibiae weight, length, mid-shaft width, proximal width, distal width, ash weight, weight to length index and relative bone density recorded in male turkeys. Size differences, as well as hormonal differences, can account for the differences in the bone quality between males and females (Rath et al., 2000). Male turkeys are mostly heavier with longer body measurements (body length, thigh length, shank length) than female turkeys and this indicated why tibiae morphometric parameters were in the favour of males. Our findings corroborated earlier report by Mabelebele et al. (2017) who indicated that bone length is related to sexual dimorphism.

The authors recorded longer tibia lengths in male indigenous and broiler chickens when compared with their female counterparts. According to Rath et al. (1999), male and female birds of the same age show different bone measurements, with the females showing a consistently lower value. In another study by Rose et al. (1996), female broiler chicken had lower tibiotarsal bone weight than males. However, robusticity index was significantly $(p<0.05)$ higher in female turkeys. This is an indication that tibiae analysed from female turkeys are much stronger than tibia from males. As defined by Ruff et al. (1993), robusticity index is the measure of the strength of a bone in relation to the mechanically relevant measure of body size of the animal.

\section{Tibiae minerals (Ca and P)}

In Table 3, the effects of housing system, feather colour and sex on tibiae minerals of turkeys is presented. Tibiae calcium content was significantly $(\mathrm{p}<0.05)$ higher $(4.31 \%)$ in turkeys reared in deep litter and lower (2.25\%) in turkeys under outdoor run houses. Also, tibiae calcium and phosphorous contents were significantly $(\mathrm{p}<0.05)$ higher ( 4.32 and $10.86 \%$ ) in female turkeys than values (2.24 and $6.49 \%$ ) recorded male turkeys. Bone mineral matrix predominantly contains $\mathrm{Ca}$ and $\mathrm{P}$ which provides rigidity to the skeletal system.
These minerals are also essential during egg shell formation in female birds. The findings of this study confirmed earlier report of Dacke et al. (1993); that maturation of ovarian follicles in female birds result in the development of bones essentially woven with a high rate of remodelling for adequate provision of calcium to meet the demand of eggshell formation. This was shown in the significant interaction between housing system and sex. In addition, the relative importance of phosphorus in bone formation was revealed in the significant interactions of sex by feather colour as well as housing system by sex by feather colour.

\section{Conclusion}

In conclusion, male turkeys with white feathers had higher body weights. However, female turkeys with either white or black feathers could be reared in outdoor run for strong tibiae with predominant bone mineral (Ca and P) matrix.

Declaration of interests. There is absolutely no conflict of interest with any individual or organisation regarding the materials discussed in the manuscript.

\section{References}

1. Ajayi FO (2010). Nigerian indigenous chicken: A valuable genetic resource for meat and egg production. Asian Journal of Poultry Science, 4(4): 164-162.

2. AOAC (1995). Official methods of analysis, 16th edition. Association of Official Analytical Chemists, Arlington, Virginia, 1995, 22201 USA.

3. Bennett MB (2008). Post-hatch growth and development of the pectoral and pelvic limbs in the black noddy, Anous minutes. Comparative Biochemistry and Physiology, 150: 159-168.

4. Bracke MBM, Hopster H (2006). Assessing the importance of natural behavior for animal welfare. Journal of Agricultural and Environmental Ethics, 19: 77-89.

5. Case LA, Miller SP, Wood BJ (2010). Factors affecting breast meat yield in turkeys. World's Poultry Science Journal, 66(2): 189-202.

6. Dacke CG, Arkle S, Cook DJ, Wormstone IM, Jones S, Zaidi M, Bascal ZA (1993). Medullary bone and avian calcium regulation. Journal of Experimental Biology, 184: 63-68.

7. Dawkins MS, Donnelly CA, Jones TA (2004). Chicken welfare is influenced more by housing conditions than by stocking density. Nature, 427: 342-344.

8. Duncan IJH (1998). Behavior and Behavioral Needs. Poultry Science, 77, 1766-1772

9. Fanatico AC, Pillai PB, Cavitt LC, Emmert JL, Meullenet JF, Owens CM (2006). Evaluation of slower-growing 
genotypes grown with and without outdoor access: sensory attributes. Poultry Science, 85: 337-343.

10. Fox TW, Smyth JR (1982). Further studies on the effects of the recessive white genotype on early growth rate and body size. Poultry Science, 61: 1585-1589.

11. Goliomytis M, Panopoulou E, Rogdakis E (2003). Growth curves for body weight and major component parts, feed consumption, and mortality of male broiler chickens raised to maturity. Poultry Science, 82: 1061-1068.

12. Havenstein GB, Ferket PR, Grimes JL, Qureshi MA, Nestor KE (2007). Comparison of the performance of 1966versus 2003-type turkeys when fed representative 1966 and 2003 turkey diets: Growth rate, livability, and feed conversion. Poultry Science, 86: 232-240.

13. Hill GE, Doucet SM, Buchholz R (2005). The effect of coccidial infection on iridescent plumage coloration in wild turkeys. Animal Behaviour, 69: 387-394.

14. Inci H, Sogut B, Sengul T, Sengul AY, Taysi MR (2015). Comparison of fattening performance, carcass characteristics, and egg quality characteristics of Japanese quails with different feather colours. Revista Brasileira de Zootecnia, 44(11): 390-396.

15. Knowles TG, Kestin SC, Haslam SM, Brown SN, Green LE, Butterworth A, Pope SJ, Pfeiffer D, Nicol CJ (2008). Leg disorders in broiler chickens: Prevalence, risk factors and prevention. PLoS One, 3: 15-45.

16. Lilburn MS (1994). Skeletal Growth of Commercial Poultry Species. Poultry Science, 73(6): 897-903.

17. Liu YL, Song GL, Yi GF, Hou YQ, Huang JW, Vazquez-Anon M, Knight CD (2006). Effect of supplementing 2-hydroxy4(methylthio) butanoic acid and DLmethionine in cornsoybean-cottonseed meal diets on growth performance and carcass quality of broilers. Asian-Australasian Journal of Animal Science, 19(8): 1197-1205.

18. Mabelebele M, Norris D, Siwendu NA, Ng'ambi JW, Alabi OJ, Mbajiorgu CA (2017). Bone morphometric parameters of the tibia and femur of indigenous and broiler chickens reared intensively. Applied Ecology and Environmental Research, 15(4): 1387-1398.

19. MacDougall AK, Montgomerie R (2003). Assortative mating by carotenoid-based plumage colour: a quality indicator in American goldfinches Carduelis tristis, Naturwissenschaften, 90: 464-467.

20. Minvielle F, Gourichon D, Monvoisin JL (2002). Testing homology of loci for two plumage colours, lavender and recessive white, with chicken and Japanese quail hybrids. Journal of Heredity, 93: 73-76.

21. Mutus MN, Kocabagli MA, Acar N, Eren M, Gezen SS (2006). The effect of dietary probiotic supplementation on tibial bone characteristics and strength in broilers. Journal of Poultry Science, 85: 1621-1625

22. NFACC - National Farm Animal Care Council (2016). Code of Practice for the care and Handling of hatching eggs, breeders, chickens and turkeys. Canadian Agri-food Research Council, Canada.

23. Noraziah M, Engku Azahan EA, Shanmugavelu S (2001). Growth performance and carcass yield of spring chickens. Proceedings of $23^{\text {rd }}$ Malaysian Society of Animal
Production (MSAP) Annual Conference, Langkawi, Malaysia, pp. 148-149.

24. NRC (1994). Nutrient Requirements for Poultry. 9th rev. ed. Natl. Acad. Press, Washington, DC.

25. Odutayo OJ, Sogunle OM, Akinosi OK, Safiyu KK, Ekunseitan DA (2015). Effect of varying litter depths on growth performance and linear body mearsurements of locally-adapted turkey poults. In: Adebiyi, O.A., Ogunwole, O.A., Babayemi O.J. \& Iyayi, E.A. (Eds.) Proceedings of the $20^{\text {th }}$ Annual Conference of Animal Science Association of Nigeria (ASAN) co-organized with Nigerian Institute of Animal Science (NIAS) pp. 525-527.

26. Ojewola GS, Udokainyang AD, Obasi V (2002). Growth, carcass and economic response of local turkey poults to various levels of dietary energy. In: Aletor V.A. and Onibi G.E. (Eds.). Increasing household protein consumption through livestock products. Proceeding of the 27th Annual Conf. of Nigeria Society for Animal Production, Akure, Nigeria. pp.167-169

27. Okeno TO, Kahi AK, Peters JK (2012). Characterization of Indigenous Chicken Rearing systems in Kenya. Tropical Animal Health and Production 44: 601-608.

28. Okoli IC, Nwaodu CH, Uchegbu MC (2009). Feeding Management Practices of Small holder Turkey Farmers in the Warm Wet Tropical Environment of Imo State, Nigeria. Report and Opinion, 1(4): 56-58.

29. Olaifa RO, Sogunle OM, Oloyede ST, Safiyu K K, Omosebi DJ, Adeyemi OA, Talabi AO, Okubanjo AO (2015). Effects of Housing system on behavioural assessment, bone morphometry and faecal egg counts of broiler chickens. Nigerian Journal of Animal Production, 42(2): 65-71.

30. Olaniyi OA, Oyenaiya OA, Sogunle OM, Akinola OS, Adeyemi OA, Ladokun OA (2012). Free-range and deep litter housing systems: effect on performance and blood profile of two strains of cockerel chickens. Tropical and Subtropical Agroecosystems, 15: 511 - 523.

31. Özhan N, Şimşek U, Özçelik M (2016). Comparison of floor and cage housing systems in terms of some welfare assessments in broiler. Ankara Üniversitesi Veteriner Fakultesi Dergisi, 63: 317-322.

32. Padhi MK (2016). Importance of Indigenous Breeds of Chicken for Rural Economy and Their Improvements for Higher Production Performance. Scientifica Volume 2016: 1-9.

33. Petek M, Ozen Y, Karakas E (2004). Effects of recessive white plumage colour mutation on hatchability and growth of quail hatched from breeders of different ages. British Poultry Science, 45: 769-774.

34. Rath NC, Balog JM, Huff WE, Huff GR, Kulkarni GB, Tierce JF (1999). Comparative differences in the composition and biomechanical properties of tibiae of seven- and seventy-two-week-old male and female broiler breeder chickens. Poultry Science, 78: 1232-1239.

35. Rath NC, Huff GR, Huff WE, Balog JM (2000). Factors regulating bone maturity and strength in poultry. Poultry Science, 79: 1024-1032.

36. Rose N, Constantin P, Leterrier C (1996). Sex differences in bone growth of broiler chickens. Growth Develop Aging, 60: 49-59. 
37. Ruff CB, Trinkaus E, Walker A, Larsen CS (1993) Postcranial robusticity in Homo I: temporal trends and mechanical interpretation. American Journal of Physical Anthropology, 91: 21-53.

38. Sarkar K, Golam M (2009). A move from subsistence to semi-commercial family poultry farming with local chickens: effective strategies for family poultry in Bangladesh. World's Poultry Science Journal 65: 251-259.

39. Seedor JG, Quarruccio HA, Thompson DD (1991). The biophosphonate alendronate (MK-217) inhibits bone loss due to ovariectomy in rats. Journal Bone Mineral Research, 6: 339-346.

40. Sogunle OM, Okusolubo OX, Olaniyi OA, Safiyu KK, Akinola OS, Ladokun AO (2014). Effects of Different Housing Systems on Growth Performance, Reproductive Organ Development and Feacal Egg Worm Counts of Two Strains of Egg-Type Chicken. Nigerian Journal of Animal Science, 16(1): 67-75.

41. Sogunle OM, Elangovan AV, David CG, Gosh J, Awachat VB (2018). Response of broiler chicken to in ovo administration of inorganic salts of Zinc, Selenium and Copper or their combination. Slovak journal of Animal Science, 51(1): 8-19.

42. Sola-Ojo FE, Ayorinde KL, Fayeye TR, Ahutu IA, Obadare AR (2016). Effect of genotype and sex on growth traits, feed utilization and survivability in Nigerian Local and Nicholas white exotic turkey. Nigerian Journal of Animal Production, 43(2): 37-49.

43. Sonaiya EB, Branckaert RDS, Gueye EF (1999). Research and development options for family poultry. First INFPD/ FAO Electronic Conference on Family Poultry.
44. Speller C (2009). Investigating Turkey (Meleagris Gallopavo) Domestication in the southwest united states through ancient DNA Analysis. Ph.D. Thesis; Simon Frazer University, Burnaby, BC, Canada.

45. Tolon B, Yalcin S (1997). Bone characteristics and body weight of broilers in different husbandry systems. British Poultry Science: 38, 132-135.

46. Turner CH, Robling AG (2004). Mechanical loading and bone formation. BoneKEy-Osteovision 1:15-23.

47. Van Wyhe RC, Regmi P, Powell BJ, Haut RC, Orth MW, Karcher DM (2014). Bone characteristics and femoral strength in commercial toms: The effect of protein and energy restriction. Poultry Science, 93: 943-952.

48. Warden S J (2006). Breaking the rule for bone adaptation to mechanical loading. Journal of Applied Physiology, 100: 1441-1442.

49. Williams RB (1996). The ratio of the water and food consumption of chickens and its significance in the chemotherapy of coccidiosis. Veterinary Research Communications, 20: 437-441.

50. Williams B, Waddington DD, Murray H, Farquharson C (2004). Bone strength during growth: Influence of growth rate on cortical porosity and mineralization. Calcified Tissue International, 74: 236-245.

51. Zhou ZL, Rath NC, Huff GR, Huff WE, Rasaputra KS, Salas C, Coon CN (2011). Bone Characteristics of 16 Wk-OldTurkeys Subjected to Different Dietary Supplements and Simulated Stress. International Journal of Poultry Science, 10(5): 332-337. 